\title{
Dendritic cell derived cytokines in human natural killer cell differentiation and activation
}

\section{Obinna Chijioke and Christian Münz*}

Viral Immunobiology, Institute of Experimental Immunology, University of Zurich, Zurich, Switzerland

\section{Edited by:}

Carsten Watzl, Leibniz Research

Centre for Working Environment and

Human Factors - IfADo, Germany

Reviewed by:

Laurel L. Lenz, National Jewish Health, USA

Evelyn Ullrich, Goethe University

Frankfurt, Germany

*Correspondence:

Christian Münz, Viral Immunobiology,

Institute of Experimental

Immunology, University of Zurich,

Winterthurerstrasse 190, Zurich

$\mathrm{CH}-8057$, Switzerland

e-mail:christian.muenz@uzh.ch
Dendritic cells (DCs) and natural killer (NK) cells shape each other's functions early during immune responses. DCs activate NK cells and NK cells can mature or kill DCs. In this review we will discuss which DC and NK cell subsets are mainly affected by this interaction, where these encounters might take place and which signals are exchanged. Finally, we will point out what the clinical benefit of understanding this interaction might be and how it changed our view on NK cells as innate lymphocytes.

Keywords: IL-18, IL-12, IL-15, IFN-alpha, immunological synapse, NKp30, DNAM-1

\section{INTRODUCTION}

Natural killer (NK) cells have originally been described by their function to spontaneously lyse tumor and infected cells (1-3). However, it has recently become apparent that they require mostly cytokine mediated activation to differentiate into effector cells and execute different effector functions - at least in humans - dependent on their differentiation stage (4-6). Three prominent cell populations that trigger this NK cell activation and differentiation have been identified. These are dendritic cells (DCs), neutrophils, and $\mathrm{CD} 4^{+} \mathrm{T}$ cells $(7-12)$. In this review we will focus on the interaction of NK cells with DCs, with an emphasis on its role in augmenting NK cell function during the innate phase of immune responses.

Human DCs are composed of different subpopulations (13) of which the two main subpopulations are conventional and plasmacytoid DCs (cDCs and pDCs). While pDCs are primarily found in primary and secondary lymphoid tissues, including bone marrow, thymus, lymph nodes, and spleen as well as blood in steady-state conditions, cDCs can be found both in lymphoid tissues and peripheral organs. Human cDCs can be subdivided in two additional subsets, $\mathrm{CD} 1 \mathrm{c}^{+}\left(\mathrm{BDCA1}^{+}\right)$and $\mathrm{CD} 141^{+}\left(\mathrm{BDCA}^{+}\right) \mathrm{DCs}$, which have now been found in the skin, liver, and lung, in addition to primary and secondary lymphoid tissues (14). In addition to these constitutive DC populations, which are at least to a substantial part dependent on Flt3L in their development $(15,16)$, inflammatory DCs can develop from monocytes. This DC lineage is dependent on GM-CSF for its development and therefore, GM-CSF constitutes an integral component of human monocytederived DC differentiation in vitro (16). Finally, Langerhans cells constitute a human DC population in the epidermis and at least in mice their steady-state maintenance is dependent on stromal IL-34 $(17,18)$. To fulfill their function DCs are equipped with molecules that sense the environment and in contrast to mice, the human DC populations have quite restricted expression patterns of pathogen associated molecular pattern (PAMP) receptors (19). For example, the toll-like receptor (TLR) nine for unmethylated DNA, which can be stimulated by CpG oligonucleotides, is only expressed by pDCs in humans, as is TLR7 for single-stranded RNA. In contrast, the double-stranded RNA receptor TLR3 is highest expressed on $\mathrm{CD} 141^{+} \mathrm{cDCs}$ and elicits high IL-12 and IFN $-\alpha / \beta / \lambda$ production from this subset. Interestingly, the IFN- $\alpha$ production by $\mathrm{CD} 141^{+} \mathrm{cDCs}$ reaches similar levels as IFN- $\alpha$ production from pDCs after TLR7 stimulation $(20,21)$. Therefore, all of these human DC populations need to be considered for NK cell activation and differentiation and will be discussed below.

\section{HUMAN NATURAL KILLER CELL SUBSET DISTRIBUTION}

Natural killer cell reactivity is guided by the balance of activating and inhibitory receptors (22). Both are acquired sequentially during development where inhibitory receptors are also instructive in NK cell education $(23,24)$. NK cell differentiation can in part be driven by both IL-15 and IL-2 in humans $(25,26)$. It is now assumed that the first functionally competent NK cell subset are $\mathrm{CD} 56^{\text {bright }} \mathrm{CD} 16^{-} \mathrm{NK}$ cells, which have lost c-kit (CD117) and IL-7R $\alpha$ (CD127) expression $(26,27)$. These seem to acquire the intermediate affinity activating Fc $\gamma$ RIII/CD16, successively down-regulate the inhibitory HLA-E receptor NKG2A/CD94 and acquire more and more inhibitory killer immunoglobulin-like receptors (KIRs) upon differentiation (28). Interestingly, at any stage CD57 expression seems to terminally differentiate the respective NK cell subset and diminish its capacity to further expand. While $\mathrm{CD} 56^{\text {bright }} \mathrm{CD} 16^{-} \mathrm{NK}$ cells respond to cytokine stimulation primarily with cytokine production, further differentiated $\mathrm{CD} 56^{\mathrm{dim}} \mathrm{CD} 16^{+} \mathrm{NK}$ cells display increased cytotoxicity and can produce a rapid, but transient cytokine burst upon tumor or infected cell encounter $(25,29)$. Interestingly, the successive 
up-regulation of KIRs seems to influence the reactivity of the later NK cell differentiation stages, depending on the expression of the cognate HLA class I ligands (24). Namely, NK cells with KIRs specific for self-HLA class I molecules have a higher reactivity against HLA class I negative tumor cell targets (30). These so-called licensed NK cells accumulate preferentially during some viral infection, primarily during persistent human cytomegalovirus (HCMV) infection (31). Some of these NK cell subset expansions allow for a more rapid response to secondary challenge with the same pathogen, which could be interpreted as an immunological memory function of the NK cell compartment $(32,33)$. These infection-experienced NK cells have been suggested to be enriched in the CXCR6 expressing hepatic NK cell subset, at least in mice (34).

The different NK cell differentiation stages have been found to be enriched at distinct anatomical sites (35). While CD56 ${ }^{\mathrm{dim}} \mathrm{CD} 16^{+} \mathrm{NK}$ cells predominate in the blood, most other tissues harbor high frequencies of $\mathrm{CD} 56^{\text {bright }} \mathrm{CD} 16^{-} \mathrm{NK}$ cells. This IFN- $\gamma$ producing NK cell subset has been originally found to mainly populate lymph nodes, tonsils, and splenic white pulp (25, 36-38). However, this NK cell differentiation stage has recently also been found to be enriched in liver, skin, uterus, joints, and tumor tissue (39-43). The CXCR6 positive NK cell subset with memorylike features might preferentially home to liver (34). Therefore, different NK cell differentiation stages can be preferentially found in distinct organs and their location might determine with which human DC populations they can preferentially interact.

\section{SITES OF INTERACTION BETWEEN HUMAN DCs AND NK CELLS}

While DCs can be found in all tissues, after activation, also called maturation, by for example TLR ligands, they migrate to or remain in secondary lymphoid tissues (13). Therefore, the interaction between mature DCs and resting NK cells would probably preferentially take place in secondary lymphoid tissues. Consistent with this notion, human NK cells and cDCs have been found to be enriched in the $\mathrm{T}$ cell zones of lymph nodes $(36,44)$. Moreover in mice, activation of NK cells in different infectious settings required DCs and homing of NK cells to secondary lymphoid tissues (45). Furthermore, injection of mature DCs resulted in the attraction of NK cells to secondary lymphoid tissues in mice (46) and brief contacts of NK cells with DCs have been observed in lymph nodes after adoptive transfer of mature DCs or in vivo activation with TLR3 and 4 ligands (47). Human secondary tissues might be especially predestined for these interactions, because CD56 ${ }^{\text {bright }} \mathrm{CD} 16^{-} \mathrm{NK}$ cells preferentially home to these sites via CCR7 and CD62L expression and are enriched at these sites $(36,44)$. Moreover, mature monocyte-derived DCs preferentially stimulate $\mathrm{CD} 56^{\text {bright }} \mathrm{CD} 16^{-} \mathrm{NK}$ cells to proliferate and produce cytokines $(37,44,48)$. Thus, NK cell activation by mature DCs probably happens primarily in the $\mathrm{T}$ cell zones of secondary lymphoid tissues including lymph nodes.

Once activated, these NK cells might then leave secondary lymphoid tissues and home to sites of inflammation. Indeed, it has been observed that NK cells and DCs co-localize in inflamed skin (49). These activated NK cells might kill immature DCs at this site in order to prevent them from transmitting tolerogenic signals to secondary lymphoid tissues (50). Indeed, NK cell killing of preferentially immature DCs has been observed, especially when activated NK cells outnumber DCs $(51,52)$. In light of the fact that in most peripheral human tissues, inflamed organs, or tumor microenvironment, it has been shown that CD56 ${ }^{\text {bright }} \mathrm{CD} 16^{-} \mathrm{KIR}^{-} \mathrm{NK}$ cells are enriched (35), it is interesting that this NK cell subset again might be preferentially killing DCs in the autologous setting without compromised MHC class I expression (53). However, NK cell reactivity might be curbed by regulatory $\mathrm{T}$ cells at these sites, who have been suggested to impair IL-2 and IL-15 mediated expansion and activation in mice (54-56). Furthermore, myeloid derived suppressor cells (MDSCs) might inhibit anti-tumor NK cell responses $(57,58)$ and their depletion by chemotherapeutika could augment their reactivity in tumors $(57,59)$. Only in conditions of infection induced down-regulation of MHC class I, as for example during HCMV infection, terminally differentiated $\mathrm{KIR}^{+} \mathrm{NKG} 2 \mathrm{C}^{+} \mathrm{CD} 57^{+} \mathrm{NK}$ cells might accumulate and then be enriched in peripheral tissues (33). Thus, NK cells might be stimulated in secondary lymphoid tissues by mature DCs and afterward might kill immature DCs at peripheral sites. Since both immature and mature DCs express significant levels of $\mathrm{MHC}$ class I molecules as ligands for inhibitory NK cell receptors, like KIRs, preferentially CD $56^{\text {bright }} \mathrm{CD} 16^{-} \mathrm{KIR}^{-} \mathrm{NK}$ cells might be involved in both interactions.

\section{SIGNALS IN HUMAN DC INTERACTION WITH NK CELLS}

According to these two different sites of interactions for DCs and NK cells, the stimulatory and killing signals that are exchanged require different molecules (Figure 1). In secondary lymphoid tissues, probably primarily cytokines are exchanged. Interleukin-12 and -18 have mainly been identified to activate cytokine production by NK cells $(37,44,60)$. In response to IL-12, NK cells primarily produce IFN- $\gamma$, TNF- $\alpha$, and GM-CSF. In contrast, IL-15 is involved in DC-stimulated NK cell proliferation, survival, and pre-activation $(44,45,61)$. Interestingly, IL- 15 only reaches the cell surface of the producing cell in complex with IL-15R $\alpha$ (62), and trans-presentation might facilitate cell contact dependent IL-15 signaling. Finally, type I IFN augments NK cell cytotoxicity (37, 63). Depending on their cytokine secreting potential, different DC subsets are therefore capable of triggering one or the other NK cell function. PDCs stimulate primarily NK cell cytotoxicity via their type I IFN producing function (63). $\mathrm{CD}^{+} \mathrm{c}^{+}$conventional and monocyte-derived human DCs are capable of producing IL-12, particularly after maturation with a TLR3 agonist $(37,63)$. Finally, Langerhans cells can support NK cell survival via their ability to present IL-15 on their surface (64). Thus, different human DC subsets stimulate distinct NK cell effector functions primarily via secretion of cytokines.

The respectively activated NK cells can then however signal back to DCs and presumably spread immune activation to neighboring secondary lymphoid tissue resident DCs (Figure 1). It has been shown that NK cell produced TNF- $\alpha$ can mature DCs (52, $65)$. This maturation can initiate adaptive $\mathrm{T}$ cell mediated immune responses against for example tumors $(66,67)$. Moreover, NK cell produced IFN- $\gamma$ can assist in the polarization of Th1 responses by DCs (46, 68-70). Particularly, IL-18 activated NK cells up-regulate secondary lymphoid tissue homing markers like CCR7, and can 

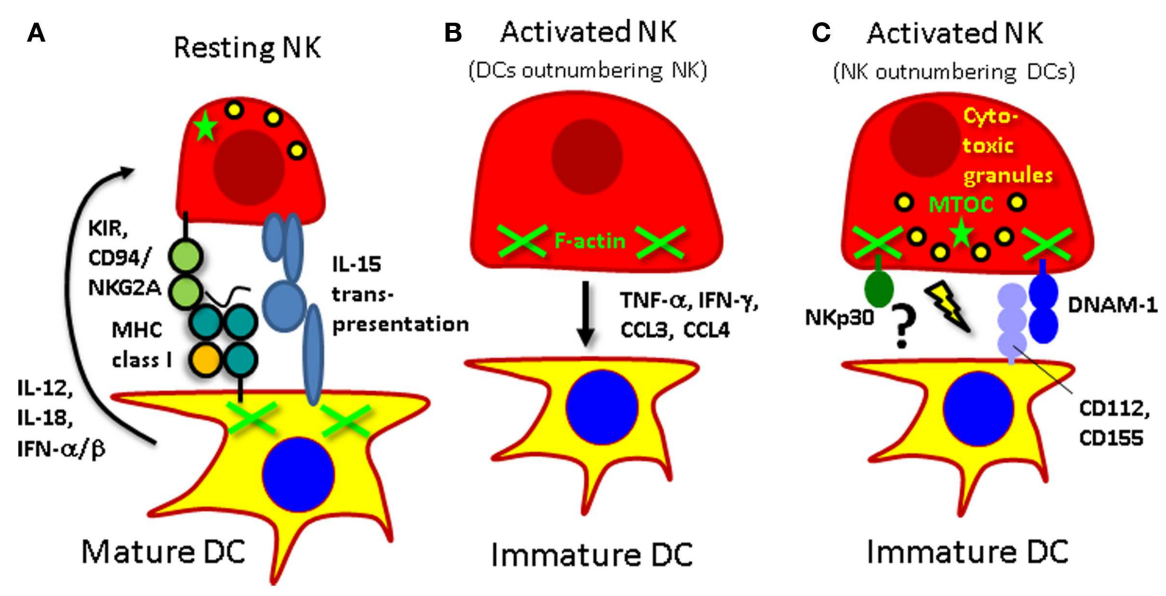

FIGURE 1 | Interactions of human NK cells with DCs. (A) Mature DCs activate resting NK cells via IL-12, IL-15, and type I IFN. At the same time NK cells receive an inhibitory signal via killer immunoglobulin-like receptors (KIRs) or CD94/NKG2A to prevent them from killing mature DCs. (B) Activated NK cells can mature DCs via secretion of TNF- $\alpha$, polarize them to produce IL-12 for Th1 induction with IFN- $\gamma$, and attract them via the CCR5 ligands CCL3 and CCL4. (C) If they, however, outnumber immature DCs they can kill these targets by perforin mediated lysis after engagement of the activating receptors NKp30 and DNAM-1. stimulate IL-12 production by DCs (71). These NK cell stimulated DCs also up-regulate CCR7 and migrate in response to its ligand CCL21 (72). Furthermore, these so-called "helper" NK cells can also stimulate DCs to produce chemokines, primarily CXCL9, CXCL10, and CCL5, which allows attraction of effector CD8 ${ }^{+} \mathrm{T}$ cells (73). Therefore, NK cells can mature DCs to preferentially home to secondary lymphoid tissues and prime Th1 responses.

Finally, the third outcome of interactions between DCs and NK cells is killing of DCs (Figure 1). It has been shown that this occurs between activated NK cells and immature DCs (51-53). At least monocyte-derived DCs are recognized by activated NK cells via their NKp30 and DNAM-1 activating receptors (51, 74-76). Mature DCs are protected from this NK cell lysis by up-regulation of MHC class I molecules, including the non-classical HLA-E molecule $(51,53)$. Thus, DCs express ligands for activating receptors on human NK cells, but are after maturation protected from NK cell lysis by increased expression of MHC class I molecules.

\section{IMMUNOLOGICAL SYNAPSES THAT MEDIATE NK CELL INTERACTION WITH DCS}

Natural killer cells interact with target cells usually via the establishment of one of two types of immunological synapses. If activating signals dominate the interaction, an activating immunological synapse is observed with actin polymerization in the NK cell, polarization of the microtubule organizing center (MTOC) to the synapse and cytotoxic granule release through the center of the synapse, which leads to the killing of the target cell (77). On the contrary, if inhibitory signals prevail, inhibitory immunological synapses do not mature with cytoskeleton rearrangement, are short lived and the NK cell dissociates from the target cell without mobilizing any effector functions (78). NK cells also interact with DCs through immunological synapses (61, 79-81). However, the outcome of the interaction between mature DCs and NK cells is NK cell activation without killing of the conjugated DC. Therefore, we termed this immunological synapse regulatory. It seems to be designed to efficiently exchange paracrine IL-12, IL-18, and IL-15 from DCs to NK cells, in order to stimulate cytokine production and survival of NK cells $(61,79,80)$. This becomes especially important when maturation stimuli allow DCs only to produce limited amounts of these cytokines and other leukocyte populations in the lymph node environment can consume these cytokines in addition to NK cells $(37,79)$. At the same time, inhibitory interactions are exchanged at the regulatory immunological synapse between mature DCs and NK cells. Inhibitory receptors like KIRs accumulate in other membrane domains than NK cell stimulatory IL-15/IL-15R $\alpha$ complexes, although both are located in the center of immunological synapses of mature DCs with resting NK cells (61). This compartmentalization of inhibitory and activating domains occurs rapidly within $5 \mathrm{~min}$ after interaction between these two leukocyte populations. Upon longer interaction, the immunological synapse between mature DCs and NK cells is then stabilized by cytoskeletal rearrangements, including actin polymerization at the synapse in the conjugated DC (81). Interestingly, these cytoskeletal rearrangements seem to primarily support the inhibitory signals that are exchanged at the synapse between DCs and NK cells, because inhibition of actin polymerization in DCs by for example decreasing the expression of Wiskott Aldrich Syndrome Protein (WASP), which organizes the actin cytoskeleton at immunological synapses, leads to conversion of the immunological synapse into an activating NK cell synapse with actin polymerization in the conjugated NK cells and killing of DCs. Therefore, human DCs seem to coordinate their interaction with NK cells via a regulatory immunological synapse, which allows exchanging at the same time stimulatory signals for NK cells and signals that inhibit them from killing DCs.

While these long-lasting synapses have been observed with human cells in vitro, DCs, and NK cells establish only short interactions, usually below $3 \mathrm{~min}$, in mouse lymph nodes (47). It is so far unknown, which species differences might cause these divergent interaction kinetics. One possibility, however, could be that 
the possible NK cell subpopulation counterpart in mice (82) of the CD56 ${ }^{\text {bright }} \mathrm{CD} 16^{-} \mathrm{NK}$ cell population, which preferentially forms conjugates with human mature DCs (61), engages in these longlasting synapses, and the respective murine NK cell subset is too rare to be readily observed in mouse lymph nodes in vivo. Alternatively, however, the short interactions in vivo could also result from additional stimuli like chemokine gradients that could sustain NK cell mobility and shorten NK cell interactions with DCs. Further in vivo imaging studies could clarify such heterogeneity of immunological synapse formation between DC and NK cell subpopulations.

\section{THERAPEUTIC POTENTIAL OF NK CELL INTERACTIONS WITH DCs}

Both NK cell activating as well as DC restricting functions in the interaction of NK cells with DCs might be harnessed for therapeutic benefit. NK cell activation by DCs during vaccination might generate a stimulatory environment for the priming of Th1 responses. Along these lines, TLR3 agonists mature DCs for optimal NK cell stimulation in vitro (37). Moreover, synthetic double-stranded RNA induced a profile beneficial for NK cell stimulation in healthy volunteers (83) and was able to augment NK cell responses against tumor cells in mice with reconstituted human immune system components (84). Therefore, the right choice of adjuvant could harness NK cells during vaccination. Cytokine production by activated NK cells can improve maturation of DCs to expand tumor specific T cells more efficiently and acquire homing markers for secondary lymphoid tissues (72). Thus, NK cell activation by DCs during vaccination could feed-back to antigen presenting cells to increase their Th1 polarizing potential.

However, a completely different clinical benefit of DC interaction with NK cells was revealed when it was noticed that alloreactive NK cell therapy by haploidentical bone marrow transplantation against acute myeloid leukemia (AML) relapse also diminished graft-versus-host-disease $(\mathrm{GvHD})(85,86)$. It was noted that NK cells were not only able to target HLA mismatched leukemia cells, but also allogeneic DCs, which then no longer can prime donor T cells, specific for the host MHC allotype, to attack the host. This NK cell reactivity against MHC mismatched DCs might also be beneficial in other transplantation settings. At least in experimental animal models, it is well documented that alloreactive NK cells eliminate DCs from allogeneic grafts (87-90). In MHC mismatched skin, pancreatic $\beta$-islet and lung transplantation, it was shown that host NK cells eliminate donor DCs from the transplant, which subsequently led to decreased priming of host derived alloreactive $\mathrm{T}$ cell responses. The resulting diminished rejection allowed the respective transplants to survive longer and to perform better. These data suggest that allogeneic DC targeting by NK cells that lack KIRs against the MHC haplotype of the graft can ameliorate GvHD by donor NK cell cytotoxicity or transplant rejection by host NK cell cytotoxicity. These clinical benefits might be augmented by adoptively transferring alloreactive NK cell lines, which could be either stimulated with TLR3 agonist matured DC populations or their cytokines in vitro. IL-12, IL-15, IL-18, and IFN- $\alpha$ should be considered as stimulatory monokines that could be used to expand functionally competent NK cell lines in vitro. Adoptively transferred NK cell lines that have been activated and expanded in this fashion might confer protection against leukemia relapse and GvHD in a haploidentical transplantation setting until NK cell populations have reconstituted from transplanted hematopoietic progenitor cells.

\section{CONCLUSION}

In recent years it has become apparent that DCs can in addition to being superior antigen presenting cells for T cell priming, activate innate lymphocytes (69). In fact, the parallels between $\mathrm{CD}^{+} \mathrm{T}$ cell priming and NK cell activation by DCs are quite striking. For both lymphocyte populations, activation happens in secondary lymphoid tissues, is dependent on IL-12 and requires IL-15 for survival (91). DCs form immunological synapses with $\mathrm{CD}^{+} \mathrm{T}$ cells and NK cells, which are stabilized by the DC cytoskeleton. Furthermore, both of them acquire cytotoxicity through this activation and loose initial cytokine production during further differentiation. Alongside, and presumably as a protective mechanism against immunopathology mediated by these cytotoxic lymphocytes, both $\mathrm{CD}^{+} \mathrm{T}$ cells and NK cells up-regulate inhibitory receptors, which safe-guard their activation upon target cell encounter. Finally, they both can kill DCs either after viral antigen presentation or virus induced MHC class I down-regulation. Therefore, it is tempting to speculate that NK cells are the evolutionarily older cousins of $\mathrm{CD}^{+} \mathrm{T}$ cells. However, it still needs to be clarified if they can also develop some sort of memory to infections through for example NK cell subset expansion in response to pathogens (33).

\section{ACKNOWLEDGMENTS}

Work in our laboratory is supported by the Sassella Foundation (10/02, 11/02, and 12/02), Cancer Research Switzerland (KFS-02652-08-2010), the Association for International Cancer Research (11-0516), KFSP ${ }^{\mathrm{MS}}$ and KFSPHLD of the University of Zurich, the Baugarten Foundation, the Sobek Foundation, Fondation Acteria, Novartis, and the Swiss National Science Foundation (310030_143979 and CRSII3_136241).

\section{REFERENCES}

1. Herberman RB, Nunn ME, Lavrin DH. Natural cytotoxic reactivity of mouse lymphoid cells against syngeneic acid allogeneic tumors. I. Distribution of reactivity and specificity. Int J Cancer (1975) 16:216-29.

2. Kiessling R, Klein E, Wigzell H. "Natural" killer cells in the mouse. I. Cytotoxic cells with specificity for mouse Moloney leukemia cells. Specificity and distribution according to genotype. Eur J Immunol (1975) 5:112-7. doi:10.1002/eji. 1830050208

3. Trinchieri G, Santoli D. Anti-viral activity induced by culturing lymphocytes with tumor-derived or virus-transformed cells. Enhancement of human natural killer cell activity by interferon and antagonistic inhibition of susceptibility of target cells to lysis. J Exp Med (1978) 147:1314-33. doi:10.1084/jem.147.5.1299

4. Moretta A. Natural killer cells and dendritic cells: rendezvous in abused tissues. Nat Rev Immunol (2002) 2:957-64. doi:10.1038/nri956

5. Barreira da Silva R, Münz C. Natural killer cell activation by dendritic cells: balancing inhibitory and activating signals. Cell Mol Life Sci (2011) 68:3505-18. doi:10.1007/s00018-011-0801-8

6. Chijioke O, Münz C. Interactions of human myeloid cells with natural killer cell subsets in vitro and in vivo. J Biomed Biotechnol (2011) 2011:251679. doi:10.1155/2011/251679

7. Fernandez NC, Lozier A, Flament C, Ricciardi-Castagnoli P, Bellet D, Suter $\mathrm{M}$, et al. Dendritic cells directly trigger NK cell functions: cross-talk relevant in innate anti-tumor immune responses in vivo. Nat Med (1999) 5:405-11. doi: $10.1038 / 7403$

8. Spörri R, Joller N, Hilbi H, Oxenius A. A novel role for neutrophils as critical activators of NK cells. J Immunol (2008) 181:7121-30. 
9. Bihl F, Pecheur J, Breart B, Poupon G, Cazareth J, Julia V, et al. Primed antigenspecific $\mathrm{CD}^{+}{ }^{+} \mathrm{T}$ cells are required for NK cell activation in vivo upon Leishmania major infection. J Immunol (2010) 185:2174-81. doi:10.4049/jimmunol. 1001486

10. Horowitz A, Behrens RH, Okell L, Fooks AR, Riley EM. NK cells as effectors of acquired immune responses: effector $\mathrm{CD}^{+}{ }^{+} \mathrm{T}$ cell-dependent activation of NK cells following vaccination. J Immunol (2010) 185:2808-18. doi:10.4049/jimmunol.1000844

11. Horowitz A, Newman KC, Evans JH, Korbel DS, Davis DM, Riley EM. Crosstalk between $\mathrm{T}$ cells and NK cells generates rapid effector responses to Plasmodium falciparum-infected erythrocytes. J Immunol (2010) 184:6043-52. doi:10.4049/jimmunol.1000106

12. Jaeger BN, Donadieu J, Cognet C, Bernat C, Ordonez-Rueda D, Barlogis V, et al. Neutrophil depletion impairs natural killer cell maturation, function, and homeostasis. J Exp Med (2012) 209:565-80. doi:10.1084/jem.20111908

13. Merad M, Sathe P, Helft J, Miller J, Mortha A. The dendritic cell lineage: ontogeny and function of dendritic cells and their subsets in the steady state and the inflamed setting. Annu Rev Immunol (2013) 31:563-604. doi:10.1146/annurevimmunol-020711-074950

14. Haniffa M, Shin A, Bigley V, Mcgovern N, Teo P, See P, et al. Human tissues contain $\mathrm{CD} 141^{\text {hi }}$ cross-presenting dendritic cells with functional homology to mouse $\mathrm{CD} \mathrm{C}^{+}$nonlymphoid dendritic cells. Immunity (2012) 37:60-73. doi:10.1016/j.immuni.2012.04.012

15. Maraskovsky E, Daro E, Roux E, Teepe M, Maliszewski CR, Hoek J, et al. In vivo generation of human dendritic cell subsets by Flt3 ligand. Blood (2000) 96:878-84.

16. Schmid MA, Kingston D, Boddupalli S, Manz MG. Instructive cytokine signals in dendritic cell lineage commitment. Immunol Rev (2010) 234:32-44. doi:10.1111/j.0105-2896.2009.00877.x

17. Greter M, Lelios I, Pelczar P, Hoeffel G, Price J, Leboeuf M, et al. Stromaderived interleukin-34 controls the development and maintenance of langerhans cells and the maintenance of microglia. Immunity (2012) 37:1050-60. doi:10.1016/j.immuni.2012.11.001

18. Wang Y, Szretter KJ, Vermi W, Gilfillan S, Rossini C, Cella M, et al. IL-34 is a tissue-restricted ligand of CSF1R required for the development of Langerhans cells and microglia. Nat Immunol (2012) 13:753-60. doi:10.1038/ni.2360

19. Iwasaki A, Medzhitov R. Toll-like receptor control of the adaptive immune responses. Nat Immunol (2004) 5:987-95. doi:10.1038/ni1112

20. Lauterbach H, Bathke B, Gilles S, Traidl-Hoffmann C, Luber CA, Fejer G, et al. Mouse CD8alpha ${ }^{+}$DCs and human $\mathrm{BDCA}^{+}$DCs are major producers of IFN-lambda in response to poly IC. J Exp Med (2010) 207:2703-17. doi:10.1084/jem.20092720

21. Meixlsperger S, Leung CS, Ramer PC, Pack M, Vanoaica LD, Breton G, et al. $\mathrm{CD}_{141^{+}}$dendritic cells produce prominent amounts of IFN-alpha after dsRNA recognition and can be targeted via DEC-205 in humanized mice. Blood (2013) 121:5034-44. doi:10.1182/blood-2012-12-473413

22. Long EO, Kim HS, Liu D, Peterson ME, Rajagopalan S. Controlling natural killer cell responses: integration of signals for activation and inhibition. Annu Rev Immunol (2013) 31:227-58. doi:10.1146/annurev-immunol-020711-075005

23. Hoglund P, Brodin P. Current perspectives of natural killer cell education by MHC class I molecules. Nat Rev Immunol (2010) 10:724-34. doi:10.1038/ nri2835

24. Parham P, Moffett A. Variable NK cell receptors and their MHC class I ligands in immunity, reproduction and human evolution. Nat Rev Immunol (2013) 13:133-44. doi:10.1038/nri3370

25. Ferlazzo G, Thomas D, Lin SL, Goodman K, Morandi B, Muller WA, et al. The abundant NK cells in human lymphoid tissues require activation to express killer cell Ig-like receptors and become cytolytic. J Immunol (2004) 172:1455-62.

26. Romagnani C, Juelke K, Falco M, Morandi B, D’Agostino A, Costa R, et al. $\mathrm{CD} 6^{\text {bright }} \mathrm{CD} 16^{-}$killer Ig-like receptor- NK cells display longer telomeres and acquire features of CD56 ${ }^{\mathrm{dim}}$ NK cells upon activation. J Immunol (2007) 178:4947-55.

27. Freud AG, Yokohama A, Becknell B, Lee MT, Mao HC, Ferketich AK, et al. Evidence for discrete stages of human natural killer cell differentiation in vivo. J Exp Med (2006) 203:1033-43. doi:10.1084/jem.20052507

28. Bjorkstrom NK, Riese P, Heuts F, Andersson S, Fauriat C, Ivarsson MA, et al. Expression patterns of NKG2A, KIR, and CD57 define a process of
CD56 ${ }^{\text {dim }}$ NK-cell differentiation uncoupled from NK-cell education. Blood (2010) 116:3853-64. doi:10.1182/blood-2010-04-281675

29. De Maria A, Bozzano F, Cantoni C, Moretta L. Revisiting human natural killer cell subset function revealed cytolytic $\mathrm{CD} 56^{\mathrm{dim}} \mathrm{CD} 16^{+} \mathrm{NK}$ cells as rapid producers of abundant IFN-gamma on activation. Proc Natl Acad Sci U S A (2011) 108:728-32. doi:10.1073/pnas.1012356108

30. Vivier E, Raulet DH, Moretta A, Caligiuri MA, Zitvogel L, Lanier LL, et al. Innate or adaptive immunity? The example of natural killer cells. Science (2011) 331:44-9. doi:10.1126/science.1198687

31. Beziat V, Liu LL, Malmberg JA, Ivarsson MA, Sohlberg E, Bjorklund AT, et al. NK cell responses to cytomegalovirus infection lead to stable imprints in the human KIR repertoire and involve activating KIRs. Blood (2013) 121:2678-88. doi:10.1182/blood-2012-10-459545

32. Paust S, von Andrian UH. Natural killer cell memory. Nat Immunol (2011) 12:500-8. doi:10.1038/ni.2032

33. Jost S, Altfeld M. Control of human viral infections by natural killer cells. Annu Rev Immunol (2013) 31:163-94. doi:10.1146/annurev-immunol-032712100001

34. Paust S, Gill HS, Wang BZ, Flynn MP, Moseman EA, Senman B, et al. Critical role for the chemokine receptor CXCR6 in NK cell-mediated antigenspecific memory of haptens and viruses. Nat Immunol (2010) 11:1127-35. doi:10.1038/ni.1953

35. Shi FD, Ljunggren HG, La Cava A, Van Kaer L. Organ-specific features of natural killer cells. Nat Rev Immunol (2011) 11:658-71. doi:10.1038/nri3065

36. Fehniger TA, Cooper MA, Nuovo GJ, Cella M, Facchetti F, Colonna M, et al. CD56 ${ }^{\text {bright }}$ natural killer cells are present in human lymph nodes and are activated by $\mathrm{T}$ cell derived IL-2: a potential new link between adaptive and innate immunity. Blood (2003) 102:3052-7. doi:10.1182/blood-2002-092876

37. Strowig T, Brilot F, Arrey F, Bougras G, Thomas D, Muller WA, et al. Tonsilar natural killer cells restrict B cell transformation by the Epstein Barr virus via IFN- $\gamma$. PLoS Pathog (2008) 4:e27. doi:10.1371/journal.ppat.0040027

38. Lünemann A, Vanoaica LD, Azzi T, Nadal D, Münz C. A distinct subpopulation of human natural killer cells restricts B cell transformation by EBV. J Immunol (published ahead of print October 9, 2013). doi:10.4049/jimmunol.1301046

39. Moffett-King A. Natural killer cells and pregnancy. Nat Rev Immunol (2002) 9:656-63. doi:10.1038/nri886

40. Dalbeth N, Gundle R, Davies RJ, Lee YC, Mcmichael AJ, Callan MF. CD56 ${ }^{\text {bright }}$ NK cells are enriched at inflammatory sites and can engage with monocytes in a reciprocal program of activation. J Immunol (2004) 173:6418-26.

41. Ottaviani C, Nasorri F, Bedini C, De Pita O, Girolomoni G, Cavani A. CD56 ${ }^{\text {bright }} \mathrm{CD} 16^{-} \mathrm{NK}$ cells accumulate in psoriatic skin in response to CXCL10 and CCL5 and exacerbate skin inflammation. Eur J Immunol (2006) 36:118-28. doi:10.1002/eji.200535243

42. Carrega P, Morandi B, Costa R, Frumento G, Forte G, Altavilla G, et al. Natural killer cells infiltrating human nonsmall-cell lung cancer are enriched in CD56 ${ }^{\text {bright }} \mathrm{CD} 16^{-}$cells and display an impaired capability to kill tumor cells. Cancer (2008) 112:863-75. doi:10.1002/cncr.23239

43. Burt BM, Plitas G, Zhao Z, Bamboat ZM, Nguyen HM, Dupont B, et al. The lytic potential of human liver NK cells is restricted by their limited expression of inhibitory killer Ig-like receptors. J Immunol (2009) 183:1789-96. doi:10.4049/jimmunol.0900541

44. Ferlazzo G, Thomas D, Pack M, Paludan C, Schmid D, Strowig T, et al. Distinct roles of IL-12 and IL-15 in human natural killer cell activation by dendritic cells from secondary lymphoid organs. Proc Natl Acad Sci US A (2004) 101:16606-11. doi:10.1073/pnas.0407522101

45. Lucas M, Schachterle W, Oberle K, Aichele P, Diefenbach A. Dendritic cells prime natural killer cells by trans-presenting interleukin 15. Immunity (2007) 26:503-17. doi:10.1016/j.immuni.2007.03.006

46. Martin-Fontecha A, Thomsen LL, Brett S, Gerard C, Lipp M, Lanzavecchia A, et al. Induced recruitment of NK cells to lymph nodes provides IFN-gamma for $\mathrm{T}(\mathrm{H}) 1$ priming. Nat Immunol (2004) 5:1260-5. doi:10.1038/ni1138

47. Beuneu H, Deguine J, Breart B, Mandelboim O, Di Santo JP, Bousso P. Dynamic behavior of NK cells during activation in lymph nodes. Blood (2009) 114:3227-34. doi:10.1182/blood-2009-06-228759

48. Vitale M, Della Chiesa M, Carlomagno S, Romagnani C, Thiel A, Moretta L, et al. The small subset of $\mathrm{CD} 56^{\text {bright }} \mathrm{CD} 16^{-}$natural killer cells is selectively responsible for both cell proliferation and interferon-gamma production upon 
interaction with dendritic cells. Eur J Immunol (2004) 34:1715-22. doi:10.1002/ eji. 200425100

49. Buentke E, Heffler LC, Wilson JL, Wallin RP, Lofman C, Chambers BJ, et al. Natural killer and dendritic cell contact in lesional atopic dermatitis skin Malassezia-influenced cell interaction. J Invest Dermatol (2002) 119:850-7. doi:10.1046/j.1523-1747.2002.00132.x

50. Steinman RM, Hawiger D, Nussenzweig MC. Tolerogenic dendritic cells. Annu Rev Immunol (2003) 21:685-711. doi:10.1146/annurev.immunol.21.120601. 141040

51. Ferlazzo G, Tsang ML, Moretta L, Melioli G, Steinman RM, Münz C. Human dendritic cells activate resting NK cells and are recognized via the NKp30 receptor by activated NK cells. J Exp Med (2002) 195:343-51. doi:10.1084/jem. 20011149

52. Piccioli D, Sbrana S, Melandri E, Valiante NM. Contact-dependent stimulation and inhibition of dendritic cells by natural killer cells. J Exp Med (2002) 195:335-41. doi:10.1084/jem.20010934

53. Della Chiesa M, Vitale M, Carlomagno S, Ferlazzo G, Moretta L, Moretta A. The natural killer cell-mediated killing of autologous dendritic cells is confined to a cell subset expressing CD94/NKG2A, but lacking inhibitory killer Ig-like receptors. Eur J Immunol (2003) 33:1657-66. doi:10.1002/eji.200390042

54. Terme M, Chaput N, Combadiere B, Ma A, Ohteki T, Zitvogel L. Regulatory T cells control dendritic cell/NK cell cross-talk in lymph nodes at the steady state by inhibiting CD4 ${ }^{+}$self-reactive T cells. J Immunol (2008) 180:4679-86.

55. Gasteiger G, Hemmers S, Bos PD, Sun JC, Rudensky AY. IL-2-dependent adaptive control of NK cell homeostasis. J Exp Med (2013) 210:1179-87. doi:10.1084/jem.20122571

56. Gasteiger G, Hemmers S, Firth MA, Le Floc'h A, Huse M, Sun JC, et al. IL-2dependent tuning of NK cell sensitivity for target cells is controlled by regulatory T cells. J Exp Med (2013) 210:1167-78. doi:10.1084/jem.20122462

57. Suzuki E, Kapoor V, Jassar AS, Kaiser LR, Albelda SM. Gemcitabine selectively eliminates splenic Gr- $1^{+} / \mathrm{CD}_{1} \mathrm{bb}^{+}$myeloid suppressor cells in tumor-bearing animals and enhances antitumor immune activity. Clin Cancer Res (2005) 11:6713-21. doi:10.1158/1078-0432.CCR-05-0883

58. Elkabets M, Ribeiro VS, Dinarello CA, Ostrand-Rosenberg S, Di Santo JP, Apte $\mathrm{RN}$, et al. IL-1beta regulates a novel myeloid-derived suppressor cell subset that impairs NK cell development and function. Eur J Immunol (2010) 40:3347-57. doi:10.1002/eji.201041037

59. Vincent J, Mignot G, Chalmin F, Ladoire S, Bruchard M, Chevriaux A, et al. 5Fluorouracil selectively kills tumor-associated myeloid-derived suppressor cells resulting in enhanced T cell-dependent antitumor immunity. Cancer Res (2010) 70:3052-61. doi:10.1158/0008-5472.CAN-09-3690

60. Chaix J, Tessmer MS, Hoebe K, Fuseri N, Ryffel B, Dalod M, et al. Cutting edge: priming of NK cells by IL-18. J Immunol (2008) 181:1627-31.

61. Brilot F, Strowig T, Roberts SM, Arrey F, Münz C. NK cell survival mediated through the regulatory synapse with human dendritic cells requires IL-15Ralpha. J Clin Invest (2007) 117:3316-29. doi:10.1172/JCI31751

62. Duitman EH, Orinska Z, Bulanova E, Paus R, Bulfone-Paus S. How a cytokine is chaperoned through the secretory pathway by complexing with its own receptor: lessons from interleukin-15 (IL-15)/IL-15 receptor alpha. Mol Cell Biol (2008) 28:4851-61. doi:10.1128/MCB.02178-07

63. Gerosa F, Gobbi A, Zorzi P, Burg S, Briere F, Carra G, et al. The reciprocal interaction of NK cells with plasmacytoid or myeloid dendritic cells profoundly affects innate resistance functions. J Immunol (2005) 174:727-34.

64. Münz C, Dao T, Ferlazzo G, De Cos MA, Goodman K, Young JW. Mature myeloid dendritic cell subsets have distinct roles for activation and viability of circulating human natural killer cells. Blood (2005) 105:266-273. doi:10.1182/blood-2004-06-2492

65. Gerosa F, Baldani-Guerra B, Nisii C, Marchesini V, Carra G, Trinchieri G. Reciprocal activating interaction between natural killer cells and dendritic cells. J Exp Med (2002) 195:327-33. doi:10.1084/jem.20010938

66. Mocikat R, Braumuller H, Gumy A, Egeter O, Ziegler H, Reusch U, et al. Natural killer cells activated by MHC class I(low) targets prime dendritic cells to induce protective CD8 T cell responses. Immunity (2003) 19:561-9. doi:10.1016/S1074-7613(03)00264-4

67. Adam C, King S, Allgeier T, Braumuller H, Luking C, Mysliwietz J, et al. DC-NK cell cross talk as a novel CD4 ${ }^{+}$T-cell-independent pathway for antitumor CTL induction. Blood (2005) 106:338-44. doi:10.1182/blood-2004-09-3775
68. Laouar Y, Sutterwala FS, Gorelik L, Flavell RA. Transforming growth factor-beta controls T helper type 1 cell development through regulation of natural killer cell interferon-gamma. Nat Immunol (2005) 6:600-7. doi:10.1038/ni1197

69. Münz C, Steinman RM, Fujii S. Dendritic cell maturation by innate lymphocytes: coordinated stimulation of innate and adaptive immunity. J Exp Med (2005) 202:203-7. doi:10.1084/jem.20050810

70. Morandi B, Bougras G, Muller WA, Ferlazzo G, Münz C. NK cells of human secondary lymphoid tissues enhance T cell polarization via IFN-gamma secretion. Eur J Immunol (2006) 36:2394-400. doi:10.1002/eji.200636290

71. Mailliard RB, Alber SM, Shen H, Watkins SC, Kirkwood JM, Herberman RB, et al. IL-18-induced $\mathrm{CD} 3^{+} \mathrm{CCR}^{+} \mathrm{NK}$ helper cells. J Exp Med (2005) 202:941-53. doi:10.1084/jem.20050128

72. Wong JL, Mailliard RB, Moschos SJ, Edington H, Lotze MT, Kirkwood JM, et al. Helper activity of natural killer cells during the dendritic cell-mediated induction of melanoma-specific cytotoxic T cells. J Immunother (2011) 34:270-8. doi:10.1097/CJI.0b013e31820b370b

73. Wong JL, Berk E, Edwards RP, Kalinski P. IL-18-primed helper NK cells collaborate with dendritic cells to promote recruitment of effector $\mathrm{CD}^{+} \mathrm{T}$ cells to the tumor microenvironment. Cancer Res (2013) 73:4653-62. doi:10.1158/ 0008-5472.CAN-12-4366

74. Vitale M, Della Chiesa M, Carlomagno S, Pende D, Arico M, Moretta L, et al. NKdependent DC maturation is mediated by TNFalpha and IFNgamma released upon engagement of the NKp30 triggering receptor. Blood (2005) 106:566-71. doi:10.1182/blood-2004-10-4035

75. Pende D, Castriconi R, Romagnani P, Spaggiari GM, Marcenaro S, Dondero A, et al. Expression of the DNAM-1 ligands, Nectin-2 (CD112) and poliovirus receptor (CD155), on dendritic cells: relevance for natural killer-dendritic cell interaction. Blood (2006) 107:2030-6. doi:10.1182/blood-2005-07-2696

76. Balsamo M, Zambello R, Teramo A, Pedrazzi M, Sparatore B, Scordamaglia F, et al. Analysis of NK cell/DC interaction in NK-type lymphoproliferative disease of granular lymphocytes (LDGL): role of DNAM-1 and NKp30. Exp Hematol (2009) 37:1167-75. doi:10.1016/j.exphem.2009.06.010

77. Orange JS. Formation and function of the lytic NK-cell immunological synapse. Nat Rev Immunol (2008) 8:713-25. doi:10.1038/nri2381

78. Huse M, Catherine Milanoski S, Abeyweera TP. Building tolerance by dismantling synapses: inhibitory receptor signaling in natural killer cells. Immunol Rev (2013) 251:143-53. doi:10.1111/imr.12014

79. Borg C, Abdelali J, Laderach D, Maruyama K, Wakasugi H, Charrier S, et al. NK cell activation by dendritic cells (DC) require the formation of a synapse leading to IL-12 polarization in DC. Blood (2004) 104:3267-3275. doi:10.1182/blood-2004-01-0380

80. Semino C, Angelini G, Poggi A, Rubartelli A. NK/iDC interaction results in IL-18 secretion by DCs at the synaptic cleft followed by NK cell activation and release of the DC maturation factor HMGB1. Blood (2005) 106:609-16. doi:10.1182/blood-2004-10-3906

81. Barreira da Silva R, Graf C, Münz C. Cytoskeletal stabilization of inhibitory interactions in immunologic synapses of mature human dendritic cells with natural killer cells. Blood (2011) 118:6487-98. doi:10.1182/blood-2011-07-366328

82. Vosshenrich CA, Garcia-Ojeda ME, Samson-Villeger SI, Pasqualetto V, Enault L, Richard-Le Goff O, et al. A thymic pathway of mouse natural killer cell development characterized by expression of GATA-3 and CD127. Nat Immunol (2006) 7:1217-24. doi:10.1038/ni1395

83. Caskey M, Lefebvre F, Filali-Mouhim A, Cameron MJ, Goulet JP, Haddad EK, et al. Synthetic double-stranded RNA induces innate immune responses similar to a live viral vaccine in humans. J Exp Med (2011) 208:2357-66. doi:10.1084/jem.20111171

84. Strowig T, Chijioke O, Carrega P, Arrey F, Meixlsperger S, Rämer PC, et al. Human NK cells of mice with reconstituted human immune system components require preactivation to acquire functional competence. Blood (2010) 116:4158-67. doi:10.1182/blood-2010-02-270678

85. Ruggeri L, Capanni M, Urbani E, Perruccio K, Shlomchik WD, Tosti A, et al. Effectiveness of donor natural killer cell alloreactivity in mismatched hematopoietic transplants. Science (2002) 295:2097-100. doi:10.1126/science. 1068440

86. Velardi A, Ruggeri L, Mancusi A. Killer-cell immunoglobulin-like receptors reactivity and outcome of stem cell transplant. Curr Opin Hematol (2012) 19:319-23. doi:10.1097/MOH.0b013e32835423c3 
87. Beilke JN, Kuhl NR, Van Kaer L, Gill RG. NK cells promote isletallograft tolerance via a perforin-dependent mechanism. Nat Med (2005) 11:1059-65. doi:10.1038/nm1296

88. Yu G, Xu X, Vu MD, Kilpatrick ED, Li XC. NK cells promote transplant tolerance by killing donor antigen-presenting cells. J Exp Med (2006) 203:1851-8. doi:10.1084/jem.20060603

89. Laffont S, Seillet C, Ortaldo J, Coudert JD, Guery JC. Natural killer cells recruited into lymph nodes inhibit alloreactive T-cell activation through perforinmediated killing of donor allogeneic dendritic cells. Blood (2008) 112:661-71. doi:10.1182/blood-2007-10-120089

90. Jungraithmayr W, Codarri L, Bouchaud G, Krieg C, Boyman O, Gyulveszi G, et al. Cytokine complex-expanded natural killer cells improve allogeneic lung transplant function via depletion of donor dendritic cells. Am J Respir Crit Care Med (2013) 187:1349-59. doi:10.1164/rccm.201209-1749OC

91. Mueller SN, Gebhardt T, Carbone FR, Heath WR. Memory T cell subsets, migration patterns, and tissue residence. Annu Rev Immunol (2013) 31:137-61. doi:10.1146/annurev-immunol-032712-095954
Conflict of Interest Statement: The authors declare that the research was conducted in the absence of any commercial or financial relationships that could be construed as a potential conflict of interest.

Received: 26 September 2013; paper pending published: 17 October 2013; accepted: 27 October 2013; published online: 11 November 2013.

Citation: Chijioke O and Münz C (2013) Dendritic cell derived cytokines in human natural killer cell differentiation and activation. Front. Immunol. 4:365. doi: 10.3389/fimmu.2013.00365

This article was submitted to NK Cell Biology, a section of the journal Frontiers in Immunology.

Copyright $(\odot 2013$ Chijioke and Münz. This is an open-access article distributed under the terms of the Creative Commons Attribution License (CC BY). The use, distribution or reproduction in other forums is permitted, provided the original author (s) or licensor are credited and that the original publication in this journal is cited, in accordance with accepted academic practice. No use, distribution or reproduction is permitted which does not comply with these terms. 